\title{
ANP32D wt Allele
}

National Cancer Institute

\section{Source}

National Cancer Institute. ANP32D wt Allele. NCI Thesaurus. Code C54328.

Human ANP32D wild-type allele is located in the vicinity of $12 q 13.11$ and is less than $1 \mathrm{~kb}$ long. This allele, which encodes acidic leucine-rich nuclear phosphoprotein 32 family member $\mathrm{D}$ protein, is involved in tumor formation. 